\title{
Uncovering Regional Clustering of High Technology SMEs: Russian Case
}

\author{
Stepan P. Zemtsov \\ Russian Academy for National Economy and Public Administration, Russian Federation \\ ${ }^{*}$ Corresponding Email: spzemtsov@gmail.com
}

Vera A. Barinova

Russian Academy for National Economy and Public Administration, Russian Federation

Denis V. Bukov

Gaidar Institute for Economic Policy, Russian Federation

Vladimir A. Eremkin

Russian Academy for National Economy and Public Administration, Russian Federation

Doi:10.5901/mjss.2015.v6n6s7p309

\section{Abstract}

The Soviet Union predetermined Russia's economic activity's location patterns. While the main forms of industry organization were territorial production complexes (TPC) - networks of industrial organizations united by a single technological process, switch to the market economy in the early 90 s destroyed economic ties within the TPC, leading to fragmentation of large enterprises and formation of a number of independent firms. Some scientists believe that this situation over the last 20 years could serve as a necessary foundation for clusters' formation. Nowadays interest in clusters in Russia is rekindled due to the need to find new support mechanisms for production and innovation in a stagnating economy. The Ministry of Economic Development of the Russian Federation has initiated a project to support pilot territorial innovation clusters with infrastructure formation funding. The aim of this work is to identify clusters as areas of geographical concentration of small and medium enterprises (SMEs) in high technology sector. Authors also try to check, whether existing cluster initiatives comply with the actual concentration of high-tech SMEs and whether there is any potential for new cluster initiatives. The present paper analysis exploits modified methodology, based on localization index. The study provides tables and maps, reflecting small and medium businesses concentration in Russian regions using evidence from high and medium-high technology industries. The authors empirically confirm the existence of traditional and well-known clusters and identify new concentrations of firms in Russia. This useful information can be used for policy advice.

Keywords: cluster identification, localization, SME, Russian regions, industrial complex, territorial innovation cluster, innovation, high technology, innovative firms

\section{Introduction}

Russia inherited pattern of economic activity's location from the Soviet Union, where the main forms of industry organization were territorial production complexes (TPC) - networks of industrial organizations united by a single technological process or a value-added chain. During 90-s, economic ties within the TPC were destroyed, leading to a drop in production levels, fragmentation of large enterprises and formation of a number of independent and often competing firms. Some scientists believe that this situation over the last 20 years could serve as a necessary foundation for formation of industrial clusters.

However, traditional industrial and agricultural clusters, formed in at the very beginning of 20th century or earlier, still exist in Russia: Ivanovo textile cluster ("Russian Manchester"), Vologda dairy cluster, Vladimir food manufacturers (dairy products, chocolate), clusters of Folk Arts (Fedoskino, Kargopol, Zhostovo, etc.), Krasnodar wine, Tula machinery, Michurinsk fruit, Ural cluster of stone craft, Ural clusters of metalwork, Arkhangelsk fish, Karelia woodworking and other clusters.

Today interest in clusters is rekindled because of the need to find new mechanisms to support production and 
innovation in a stagnating economy in Russia. The Ministry of Economic Development of the Russian Federation has developed a project to support pilot territorial innovation clusters by providing funding for infrastructure formation. The program requires establishment of a cluster development centre or other management structure. Selection of cluster initiatives is based on applications from existing innovation clusters. In fact, in most cases it is the regional government, who initiates application process, due to its interest in attraction of additional investment.

Certainly, pilot innovation clusters, identified by the Ministry of Economic Development, cannot be viewed as clusters in its "classical" definition, and certainly the number of Russian clusters is not limited to them. There are many other cluster initiatives, which arise not in innovative sectors, as shown in studies of the Russian Cluster Observatory (Note 1). The methods of cluster identification used by the Observatory are among other things based on the clusters' self-definition, but criteria are much softer. That is, the minimal criterion is the application itself. International experience shows that cluster initiatives can be an effective mechanism for regional development. There are certain forms of support for interaction between cluster members from the regional administrations (Ketels at al., 2012).

Yet while many potential clusters in Russia do not emerge due to the high level of distrust between firms, lack of potential benefits' understanding, etc., there is a possibility to identify these clusters using geographical proximity (high concentration) of firms. In our opinion, in Russia identification of such geographical concentrations of economic agents is important for promotion of further cluster initiatives.

The aim of this work is to identify clusters as areas of geographical concentration of small and medium enterprises (SMEs), and the main research object is SMEs in high technology sector. We try to check, whether current innovation cluster initiatives (experience of the Ministry of Economic Development) correspond to the concentration of high-tech firms and whether any potential for promotion of cluster initiatives and fostering clusters' formation exists.

In this work, we use analytical method based on localization index. The data is mostly collected from RUSLANA database (Note 2), which contains information about Russian firms. The main result of this study is high-tech SMEs' concentration assessment and representation of this concentration on corresponding maps. Analysis findings confirm existence of traditional and well-known clusters and identify previously unknown concentrations of firms that still have not declared their interaction.

The article is structured as following. The second chapter is devoted to the overview of theoretical and empirical studies about SME's cluster development and is designed to answer the question 'Why is it important for SMEs to be clustered?' The third part of the article is about definition and different methods of cluster identification. The fourth part consists of calculations using our method for cluster identification in high technology sector. The brief description of the Russian cluster policy is in the last chapter.

\section{Theoretical Bases of Firms' Clustering}

Economic activity in general has extremely uneven territorial distribution: urban agglomerations are changed to unpopulated territories. Economic activity thus depends on concentration of and interaction between people, firms, regional and national communities (Duranton \& Puga, 2004).

As evolutionary ideas and institutional approach (North, 1990) in social sciences developed, the category "locality" as a combination of natural-historic conditions and socio-economic factors became one of the most important in regional science. Historically developed set of conditions influences current development of local communities, in particular within the concept of path dependency (Boschma \& Martin, 2010). Innovation development in regions depends on spatial specifics: degrees of concentration, proximity, coherence and a variety of innovation agents and knowledge flows intensity between them (see, for example, Crescenzi \& Rodríguez-Pose, 2011).

The models of new economic geography of P. Krugman (Krugman, 1991) had an essential impact on modern ideas of role of distance in social and economic processes. In consequence of the scale effect, firms seek to centre production near markets and suppliers. It creates an agglomeration. If this is not the case, centrifugal force, for example, generated by immobility of an agrarian sector, creates low-density space; similar effect can be observed when industrial firms tend to move to regions with smaller number of local competitors.

It is widely accepted, that increasing return from firms' concentration is an external economy, as contrasted to internal economies of scale. There is a discussion about the reasons of these concentration effects. The first explanation is connected with effects of clustering (localization), or Marshall's effects (Marshall, 1920; Arrow, 1962; Romer, 1986), the second - with effects of urbanization (agglomeration), or Jacobs effects (Jacobs, 1969). Effects of clustering arise from localization of the similar industries firms; urbanization effects can be shown in two dimensions: economy from concentration and economy from diversification of activity (Boschma \& lammarino, 2009). Urbanization externalities are connected with the city size (Rosenthal \& Strange, 2003; Neffke et al., 2011). 
Empirical works use the concentration of economic activity (expressed in shares, in localization indexes, in density of population and so forth) or a variety of activities (Gini, Herfindal-Hirshman, Shannon's entropy indexes etc.) as an independent variable. Employment, GRP, productivity growth can serve as a dependent variable. The paper (Beaudry \& Schiffauerova, 2009) provides generalized results of the majority of publications on the subject of externalities: clustering effects show positive significant influence in $47 \%$ of cases, and urbanization effects - in $45 \%$.

The first effect forms a basis of cluster approach (Porter, 1998), including industrial districts (Marshall, 1890; Asheim, 1996; Albino et al., 2006). The second effect, suitable for studying variety of economic activities and their impact on social and economic development, is more connected with the concepts of agglomeration effects (Audretsch, 1998; Fujita et al., 2001), regional innovation systems, "self-learning regions" and milieux (Aydalot, 1988).

Scientific knowledge and innovations as a public benefit provide indivisibility, opportunity to use unlimited number of times and in various spheres of action, impossibility to exclude other agents from knowledge transfer (Nelson, 1971; Romer, 1990). Therefore, innovation generates positive effects for other agents (Coe \& Helpman, 1995; Park, 1995).

Intensive interaction of innovation agents leads to knowledge spillovers (Acs et al., 1994; Feldman \& Audretsch, 1999; Audretsch \& Lehmann, 2005; Acs et al., 2009), labour productivity growth in a region in general. Knowledge spillover implies that the knowledge, created by one company, can be used by another one without compensation, or with compensation smaller, than the cost of the knowledge (Pilyasov, 2012). The role of knowledge spillovers in hi-tech clusters in creation of innovation projects and in support of high innovation activity is proved by a wide range of success stories in the USA (Silicon valley, Seattle, Route 128, etc.), in Canada (Montreal) and in other countries (Saxenian, 1991; Anselin et al., 1997; Carlsson, 2013).

Every industry has a tacit knowledge, which cannot be formalized, and is transferred from the teacher to the pupil only during their interaction (Polani, 1985; Asheim \& Coenen, 2005). Regional and local levels of research are preferable because of tacit knowledge localization.

Knowledge transfer intensity depends on proximity of agents, and not only spatial proximity is important (Boschma, 2005; 2009) but cognitive, organizational (the degree of unity of governing bodies), social (credibility between contractors), institutional (degree of institutes' unity), and technological (the degree of technologies compatibility) are also essential. It is a prerequisite that geographical proximity may reflect all other types.

Traditionally, cluster is defined as a group of interconnected and geographically concentrated companies with specialized suppliers, service providers, and other connected organizations (including universities, scientific centres, etc.) in one or several industries (Porter, 1998). M. Porter emphasizes (Porter, 2003) that geographical proximity of competitors can be favourable in connection with several factors:

- access to specialized factors of production and labour: availability in the district of necessary resources, equipment manufacturing, business services, qualified personnel, etc.; and also access to specialized organizations and public benefits: personnel training programmes, stimulating policy of local authorities, access to technology transfer centres, etc.;

- access to specific knowledge and competences, including tacit knowledge: extensive data on production technologies, marketing and other specialized knowledge can be collected in clusters;

- complementarity of firms: various services within one production cycle (for example, transport, recycling, etc.), or within an innovation cycle (universities - the scientific organizations - private companies);

- high innovation activity of firms (Note 3): members of a cluster constantly interact and adopt the newest developments of each other;

- high speed of knowledge commercialization due to appropriate support from local authorities, affordability of skilled personnel, etc.

Enright (1999) paid special attention to regional specific features of clusters. The scientist considers regional level of country's competitiveness, where the major role is played by historical background of development, variety of business cultures, concentration of specific competences and many other things. Regional cluster, according to $\mathrm{M}$. Enright, is a geographical agglomeration of firms, working in one or several related branches of economy.

Array of empirical researches show the significant role of clusters, that consists in increase of firms' competitiveness (Porter, 1998); in new firms' formation (Bresnahan et al., 2001; Feldman, 2001; Armington \& Acs, 2002; Fritsch \& Mueller, 2007); in firms' survival (Staber, 2001; Fritsch et al., 2006; Wennberg \& Lindqvist, 2010); in increase of profitability of the SMEs within clusters (Zhang \& Li, 2008); in rise in SMEs' export (Bair \& Gereffi, 2001; Love \& Ganotakis, 2013); in innovation business formation (Saxenian, 1996; Baptista, 1999; Cooke \& Schwartz, 2007).

The classical theories lack the analysis of service and creative industries: entertainments, tourism, scientific activity and other. And educational and scientific organizations were considered to be less important objects of research. 
Nowadays, economists more often tend to focus on scientific and technological interaction within clusters (Karlsson, 2008), and the main object moved to high-tech or creative clusters development (Keeble \& Wilkinson, 1999; Wever \& Stam, 1999; Wright et al., 2008; Lazzeretti et al., 2008; Love \& Ganotakis, 2013), especially in connection with management initiatives.

Bresci and Lissoni (2001a, b), and Lorentzen (2005) criticize the clustering approach, indicating limitation of its prerequisites. Firstly, readiness of organizations to share knowledge in a competitive environment raises doubts. Empirical researches show that knowledge flow in a cluster does not occur as easy as it is considered to be. Secondly, there is no general database, where enterprises bring data and from where they can take them. Finally, the tacit knowledge is imparted not because of geographical, but mostly due to social, technological and other types of proximity.

\section{Clusters Identification Methods}

According to M. Porter's approach, "cluster" represents a group of interdependent companies and institutes, functioning in a certain area and interconnected by their complementarity (Porter, 2000, p. 16). However, this definition seems to be at the same time both incomplete and excessively detailed. Today the concept of a cluster is quite developed and widely used in the scientific researches; therefore, definition of a cluster in many respects depends on research objectives and the methods chosen (Table 1).

Table 1. Cluster definitions and corresponding clusters identification methods

\begin{tabular}{|c|c|c|c|c|}
\hline Definition & Authors & $\begin{array}{l}\text { Possible } \\
\text { specification }\end{array}$ & Identification methods & Comments \\
\hline $\begin{array}{l}\text { group of firms from one } \\
\text { industry, concentrated in } \\
\text { one area (for example, on } \\
\text { borders of the region, city, } \\
\text { etc.) }\end{array}$ & $\begin{array}{l}\text { Porter, 1998, } \\
\text { Enright, 1999, } \\
\text { Duranton \& } \\
\text { Overman, } \\
\text { 2008; Ellison \& } \\
\text { Glaeser, } 1997\end{array}$ & $\begin{array}{l}\text { Potential } \\
\text { cluster }\end{array}$ & $\begin{array}{l}\text { indexes of economic activity } \\
\text { concentration: Ellison-Glaeser, } \\
\text { Duranton-Overman and others }\end{array}$ & $\begin{array}{l}\text { minimum possible requirements for cluster } \\
\text { identification according to potential cluster effects }\end{array}$ \\
\hline $\begin{array}{l}\text { group of firms } \\
\text { concentrated in one area } \\
\text { from one or several } \\
\text { interconnected industries }\end{array}$ & $\begin{array}{l}\text { Porter, 1998; } \\
\text { Enright, } 1999\end{array}$ & Protocluster & $\begin{array}{l}\text { calculation of localization } \\
\text { coefficient and subsequent } \\
\text { correlation coefficients between } \\
\text { different industries; balance } \\
\text { method }\end{array}$ & $\begin{array}{l}\text { there is a new criterion of interrelation between } \\
\text { industries for interindustry clusters identification }\end{array}$ \\
\hline $\begin{array}{l}\text { group of interacting firms } \\
\text { concentrated in one area } \\
\text { from one or several } \\
\text { interconnected industries }\end{array}$ & Porter, 1998 & Protocluster & $\begin{array}{l}\text { methods of sociological polls, } \\
\text { analysis of cluster initiatives and } \\
\text { network analysis for interaction } \\
\text { identification }\end{array}$ & $\begin{array}{l}\text { a new criterion of firms' interaction already brings } \\
\text { elements for cluster policy, but it is really difficult } \\
\text { to reveal interaction in practice; it is possible to } \\
\text { assume that existence of a cluster initiative is the } \\
\text { minimum criterion of firms interaction }\end{array}$ \\
\hline $\begin{array}{l}\text { group of interacting firms } \\
\text { concentrated in one area } \\
\text { form one or several } \\
\text { technologically } \\
\text { interconnected industries }\end{array}$ & $\begin{array}{l}\text { Kolosovskiy, } \\
1947\end{array}$ & $\begin{array}{l}\text { Territorial } \\
\text { production } \\
\text { complex } \\
\text { (TPC) }\end{array}$ & $\begin{array}{l}\text { power-production cycle analysis, } \\
\text { balance methods, elements of the } \\
\text { graph theory for technological } \\
\text { interaction analysis }\end{array}$ & $\begin{array}{l}\text { existence of technological interaction was the } \\
\text { main criterion for TPC identification, based on } \\
\text { the idea that similar group of resources was } \\
\text { processed in TPC, increasing extraction } \\
\text { coefficient, diminishing ecological pollution, etc. }\end{array}$ \\
\hline $\begin{array}{l}\text { group of interacting firms } \\
\text { concentrated in one area } \\
\text { from one or several } \\
\text { technologically } \\
\text { interconnected industries } \\
\text { within scientific-industrial } \\
\text { complex }\end{array}$ & $\begin{array}{l}\text { Feldman, } \\
2001, \\
\text { Lindqvist, } 2009\end{array}$ & $\begin{array}{l}\text { Territorial } \\
\text { innovation } \\
\text { cluster (TIC) }\end{array}$ & $\begin{array}{l}\text { analysis of patent citation, joint } \\
\text { publications of firms in a cluster, } \\
\text { studying of objects of intellectual } \\
\text { property, elements of the graph } \\
\text { theory }\end{array}$ & $\begin{array}{l}\text { the last researches connect benefits from a } \\
\text { clustering with the knowledge spillovers from } \\
\text { universities to firms; therefore existence of an } \\
\text { innovative component is important in a cluster }\end{array}$ \\
\hline $\begin{array}{l}\text { group of interacting firms } \\
\text { concentrated in one area } \\
\text { from one or several } \\
\text { technologically } \\
\text { interconnected industries } \\
\text { within scientific-industrial } \\
\text { complex with a system of } \\
\text { management }\end{array}$ & $\begin{array}{l}\text { Ketels et al., } \\
2012\end{array}$ & $\begin{array}{l}\text { TIC with a } \\
\text { system of } \\
\text { management }\end{array}$ & $\begin{array}{l}\text { official requests for receiving } \\
\text { subsidies from clusters initiatives; } \\
\text { analysis of web-sites information, } \\
\text { sociological methods (in particular } \\
\text { case-study), etc. }\end{array}$ & $\begin{array}{l}\text { the major criterion for implementation of cluster } \\
\text { policy - existence of cluster management, } \\
\text { institutes and their efficiency, etc. }\end{array}$ \\
\hline $\begin{array}{l}\text { group of interacting firms, } \\
\text { concentrated in one area } \\
\text { from one or several } \\
\text { technologically } \\
\text { interconnected industries }\end{array}$ & $\begin{array}{l}\text { Breschi \& } \\
\text { Lissoni, 2001a }\end{array}$ & $\begin{array}{l}\text { efficient TIC } \\
\text { with a system } \\
\text { of } \\
\text { management }\end{array}$ & $\begin{array}{l}\text { regression analysis to estimate } \\
\text { difference in profits between } \\
\text { participants of a cluster and out of } \\
\text { it, a method of stochastic border } \\
\text { analysis (SFA) and data }\end{array}$ & $\begin{array}{l}95 \% \text { of identified clusters do not correspond to } \\
\text { this definition because it is very difficult to reveal } \\
\text { efficiency, to prove that efficiency is connected } \\
\text { with cluster synergetic effect (it is known, for } \\
\text { example, that in the cities agglomerative effects }\end{array}$ \\
\hline
\end{tabular}


within scientific-industrial complex with a system of management, having the synergetic (cluster) effects and forming a system with high efficiency

Each definition and every method correspond to a certain level of cluster development. Therefore, it is possible to build cluster hierarchy on its level of development; but stages do not always follow one by one and passing through all of the stages is important not for all clusters. Various combinations of elements from different stages may also exist. Thus, these definitions refer to territorial clusters, but there are other approaches for industrial clusters identification, which may not have a territorial binding.

According to the observed literature, there are four groups of methods for clusters' identification: analysis of inputoutput tables, a distance-based methods (E. Marcon, G. Lindqvist, G. Duranton et al.), based on the calculation of localization index (M. Porter, method of the Boston Consulting Group, et al.) and qualitative methods (interviews, compiling genealogical tree, cases, etc.). Each method has its advantages and disadvantages in context of Russian specifics. Analysis of input-output tables is impossible due to the lack of sufficient and necessary statistics. The absence of necessary data on small businesses and their geographical coordinates hamper distance-based methods. It is impossible to use qualitative methods in cases, when initially we do not know about existence of the cluster. Therefore, only a combination of techniques allows most closely approximate the identification of the actual spatial patterns of hightech small and medium business.

Our analytical technique is based on M. Porter's (Porter, 2003; Quah \& Simpson, 2003) and European cluster initiative (Europe Innova, 2008; Lindqvist, 2009) approaches. The classical method was modified and instead of one, we calculated three indexes characterizing the number of SMEs, employment and sales of firms in considered industry in the region (Porter, 2003).

$$
\mathrm{LQ}=\frac{E m p_{i g}}{E m p_{g}} / \frac{E m p_{i}}{E m p}
$$

where

$L Q$ - «localization coefficient»

$E m p_{i g}-$ number of SMEs' employees (firms, sales) in industry $i$ in region $g$

$E m p_{g}$ - number of SMEs' employees (firms, sales) in the region $g$

Empi - number of SMEs' employees (firms, sales) in industry $i$ in Russia

Emp - total number of SMEs' employees (firms, sales) in Russia

Size $=\frac{E m p_{i g}}{E m p_{i}}$

where

Size - size of industry $i$ in region $g$

$E m p_{i g}-$ number of SMEs' employees (firms, sales) in industry $i$ in region $g$

$E m p_{i}-$ number of SMEs' employees(firms, sales) in industry i in Russia

Focus $=\frac{E m p_{i g}}{E m p_{g}}$

Focus - «focus» of industry I in region $g$

$E m p_{i g}$ - number of SMEs' employees (firms, sales) in industry $i$ in region $g$

$E m p_{g}$ - number of SMEs' employees (firms, sales) in region $g$

Every region gets a 'star' for an industry if:

- The region has "Localization Coefficient" $\geq 2$;

- The region is among $10 \%$ of the regions, leading on an indicator "Size";

- The region is among $10 \%$ of the regions, leading on an indicator "Focus".

The most important advantage of the proposed methodology is its ability to identify clusters in regions with a lot of small and medium enterprises by number of firms. In such cases sales and employment indicators cannot be useful. Using three indicators helps to verify the results. 


\section{Calculation of Localization Coefficient in Russian High- and Medium-high-tech Industries}

Russian cluster policy is mostly focused on knowledge based industries (Abashkin et al., 2012; Zemtsov et al., 2015), and according to theoretical base high technology industries are prone to obtaining an external economy. That is why, we were primarily interested in high-tech sectors localization. OECD identified the following industries, falling into the category of high technology industries, according to their global technological intensity: aerospace, computers and office machinery, electronics-communications, and pharmaceuticals (Hatzichronoglou, 1997). In addition, five more industries are assigned to medium-high-tech: scientific instruments, motor vehicles, electrical machines excluding communication equipment, chemicals excluding drugs, other transport and non-electrical machinery. All this industries were analysed using the method, described above, but only the most developed industries in Russia are represented in the table 2.

Table 2. The regions-leaders for potential high-tech clustering

\begin{tabular}{|c|c|c|c|c|c|c|c|}
\hline \multirow[t]{2}{*}{ Regions-leaders } & \multicolumn{2}{|c|}{ Firms } & \multicolumn{2}{|c|}{ Employees } & \multicolumn{2}{|c|}{ Sales } & \multirow{2}{*}{$\begin{array}{c}\text { All stars } \\
(\max =9 ; \min =3)\end{array}$} \\
\hline & $\mathbf{N}$ & Stars & $\mathbf{N}$ & Stars & mln USD & Stars & \\
\hline \multicolumn{8}{|c|}{$\begin{array}{l}\text { High-technology industries } \\
\text { Aerospace industry }\end{array}$} \\
\hline The Republic of Tatarstan & 51 & 3 & 7218 & 1 & 996 & 2 & 6 \\
\hline Moscow & 412 & 3 & 15660 & 1 & 2940 & 1 & 5 \\
\hline Rostov region & 20 & 1 & 10569 & 2 & 806 & 2 & 5 \\
\hline Samara Region & 39 & 2 & 20683 & 2 & 540 & 1 & 5 \\
\hline The Republic of Bashkortostan & 10 & 0 & 17196 & 2 & 940 & 2 & 4 \\
\hline Saint-Petersburg & 56 & 1 & 8223 & 1 & 720 & 1 & 3 \\
\hline Moscow region & 150 & 3 & 5649 & 0 & 300 & 0 & 3 \\
\hline Perm Region & 11 & 0 & 7217 & 1 & 554 & 2 & 3 \\
\hline The Republic of Buryatia & 3 & 0 & 5766 & 1 & 1123 & 2 & 3 \\
\hline Ulyanovsk region & 18 & 3 & 20 & 0 & 10 & 0 & 3 \\
\hline Yaroslavl region & 3 & 0 & 14740 & 2 & 355 & 1 & 3 \\
\hline \multicolumn{8}{|c|}{ Office, accounting and computing machinery } \\
\hline Saint-Petersburg & 303 & 2 & 2131 & 2 & 611 & 2 & 6 \\
\hline Moscow & 1336 & 3 & 14391 & 2 & 2248 & 1 & 6 \\
\hline Penza region & 18 & 0 & 1468 & 2 & 79 & 2 & 4 \\
\hline Kaliningrad region & 44 & 1 & 125 & 0 & 86 & 2 & 3 \\
\hline Moscow region & 179 & 1 & 1184 & 1 & 93 & 1 & 3 \\
\hline \multicolumn{8}{|c|}{ Biotechnology and pharmaceuticals } \\
\hline Moscow & 1238 & 3 & 19983 & 1 & 7798 & 1 & 5 \\
\hline Vladimir region & 33 & 1 & 1415 & 1 & 313 & 2 & 4 \\
\hline Kaluga region & 43 & 2 & 377 & 0 & 302 & 2 & 4 \\
\hline Moscow region & 225 & 2 & 7374 & 1 & 1015 & 1 & 4 \\
\hline Altai region & 39 & 0 & 1991 & 2 & 299 & 1 & 3 \\
\hline Saint Petersburg & 226 & 1 & 7014 & 1 & 622 & 1 & 3 \\
\hline Kurgan region & 5 & 0 & 4016 & 2 & 129 & 1 & 3 \\
\hline Kursk region & 7 & 0 & 1744 & 1 & 494 & 2 & 3 \\
\hline The Republic of Mordovia & 3 & 0 & 1983 & 2 & 44 & 1 & 3 \\
\hline Orenburg region & 68 & 3 & 129 & 0 & 5 & 0 & 3 \\
\hline \multicolumn{8}{|l|}{ Communication equipment } \\
\hline Saint Petersburg & 236 & 1 & 2317 & 2 & 441 & 2 & 5 \\
\hline Leningrad region & 78 & 2 & 203 & 1 & 502 & 2 & 5 \\
\hline Vladimir region & 27 & 0 & 1383 & 2 & 49 & 2 & 4 \\
\hline Kaluga region & 22 & 0 & 813 & 2 & 1737 & 2 & 4 \\
\hline Moscow & 746 & 1 & 2173 & 1 & 403 & 1 & 3 \\
\hline Moscow region & 237 & 2 & 174 & 0 & 50 & 1 & 3 \\
\hline \multicolumn{8}{|c|}{$\begin{array}{l}\text { Medium-high-technology industries } \\
\text { Medical instruments }\end{array}$} \\
\hline The Republic of Tatarstan & 170 & 2 & 2037 & 2 & 57 & 1 & 5 \\
\hline Saint Petersburg & 486 & 2 & 4267 & 1 & 330 & 1 & 4 \\
\hline Moscow & 1335 & 2 & 12801 & 1 & 1261 & 1 & 4 \\
\hline Moscow region & 260 & 2 & 3542 & 1 & 243 & 1 & 4 \\
\hline
\end{tabular}




\begin{tabular}{|c|c|c|c|c|c|c|c|}
\hline Nizhny Novgorod Region & 145 & 2 & 2113 & 2 & 45 & 0 & 4 \\
\hline Krasnodar region & 107 & 1 & 219 & 0 & 199 & 2 & 3 \\
\hline The Republic of Mordovia & 10 & 0 & 1310 & 2 & 12 & 1 & 3 \\
\hline Ryazan region & 28 & 0 & 777 & 1 & 72 & 2 & 3 \\
\hline Sverdlovsk region & 173 & 1 & 1422 & 1 & 94 & 1 & 3 \\
\hline Tambov region & 13 & 0 & 1898 & 2 & 48 & 1 & 3 \\
\hline \multicolumn{8}{|l|}{ Automobile industry } \\
\hline Nizhny Novgorod region & 271 & 3 & 18253 & 2 & 8589 & 2 & 7 \\
\hline Samara region & 436 & 3 & 25040 & 2 & 7818 & 2 & 7 \\
\hline Ulyanovsk region & 143 & 3 & 29576 & 2 & 1656 & 1 & 6 \\
\hline Republic Of Tatarstan & 319 & 3 & 5805 & 0 & 5784 & 2 & 5 \\
\hline Chelyabinsk region & 237 & 3 & 11658 & 1 & 1267 & 0 & 4 \\
\hline Moscow & 448 & 1 & 14733 & 1 & 5778 & 1 & 3 \\
\hline Saint-Petersburg & 206 & 1 & 7557 & 1 & 8772 & 1 & 3 \\
\hline Kaluga region & 43 & 1 & 2728 & 0 & 9110 & 2 & 3 \\
\hline Yaroslavl region & 51 & 1 & 21767 & 2 & 755 & 0 & 3 \\
\hline
\end{tabular}

High-tech industries are mostly concentrated in the regions with the largest agglomerations: Moscow, Saint-Petersburg, Nizhny Novgorod, Samara, Kazan (The Republic of Tatarstan), Novosibirsk, Rostov. The largest cities and former forbidden towns are the main sources of new technologies (Baburin \& Zemtsov, 2013; Zemtsov, 2014). The largest agglomerations are also the main markets for innovative products because of high incomes and higher skill level of citizens (Baburin \& Zemtsov, 2014). Most of the identified clusters are based on soviet defence industry enterprises, but none the less, several new clusters appeared. It is important to have more than 50 firms in one cluster for proper cluster identification (Ketels et al., 2012).

Aerospace industry is a traditional Russian high tech industry, which is renowned for its military branch (fighter jets, helicopters, etc.). It is highly concentrated in well-known aerospace centres (Moscow, Rostov, Samara, Ulyanovsk regions), where the main factories of "United Aircraft Corporation" are located. Nevertheless, the highest localization level is achieved in Tatarstan, where several large factories of the new integrated corporation "Russian Helicopters" are situated and where several new small firms-suppliers have appeared in recent times.

Office, accounting and computing machinery industry is located in the largest Moscow and Saint-Petersburg agglomerations. High industry's development level in Moscow is achieved due to preservation and development of the "Soviet silicon valley" in Zelenograd (part of Moscow, see fig. 2). It may be noted, that some new clusters are also forming, for example, in Kaliningrad and Penza regions. There are several foreign assembly plants in Kaliningrad region. The well-known "General Satellite" corporation constructed a complex of specialized factories in so-called "Technopolis GS" in Gusev. It is the first attempt to create a private innovation cluster in Russia.

Science Cities, like Pushchino in Moscow region, Obninsk in Kaluga region and Biysk in Altay region underlie the formation of potential biotech clusters and well-functioning pharmaceutical clusters. A new forward-looking cluster is forming in Vladimir, and there is a lot of advancing SME's in Orenburg region that play an important role in further industry development. Growth in biotech and pharma industries is promoted by rapid development of fundamental science and intensification of competition with multinational corporations (KRKA, Servier, STADA, Takeda), which already have or are currently constructing new factories in Russia.

Communication equipment plants are mostly located in metropolitan areas (Moscow and Saint-Petersburg (Leningrad) regions), where specialized universities and highly-qualified personnel are concentrated. Vladimir and Kaluga are the fledgling centres that make use of military communication technologies that were developed in the USSR. The industry started to grow fast in $2000^{\text {th }}$ due to intensive diffusion of mobile and internet technologies in Russia (Baburin \& Zemtsov, 2014), and as a result of that growth the corporation VimpelCom Ltd (originally Russian) became the sixth world's largest mobile carrier by number of subscribers.

Medical instruments production is also concentrated in the main Russian innovation centres (Moscow and Saint Petersburg), but new clusters are forming in The Republic of Tatarstan, Nizhny Novgorod Region and Krasnodar region. The industry has a high growth potential due to ongoing modernization of health care system in Russia.

Automobile industry was developing rapidly in $2000^{\text {th }}$ owing to foreign investment of the largest multinational corporations: Volkswagen, Toyota, Nissan, Volvo, Hyundai, etc. There are emerging clusters of SMEs (mostly suppliers of automotive components) around the large soviet and new factories.

The figure 1 shows results of index calculations, characterizing number of SMEs in automobile industry. Similar maps were developed for employment and sales indicators in all high-tech industries. This geographical method is very 
helpful for regional and interregional potential cluster identification and for understanding of the main localization factors. It is obvious that most of automobile clusters are located nearby the largest markets: Moscow, Kaluga, Nizhniy Novgorod, Tatarstan, Samara; and all of them can be grouped in interregional clusters: Volga (Samara, Ulyanovsk regions, Tatarstan), Moscow (Moscow, Moscow and Kaluga regions), Baltic (Saint Petersburg, Leningrad and Kaliningrad regions) and Ural (Chelyabinsk and Kurgan regions). This fact can be explained by necessity of wide cooperation between manufacturers and component suppliers.

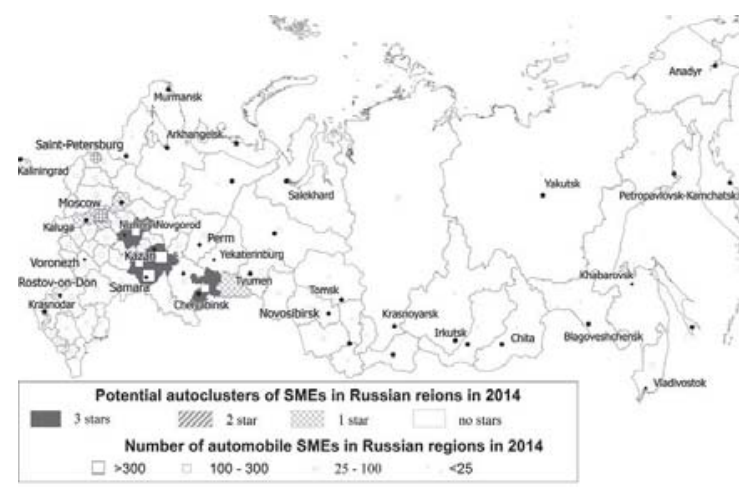

Figure 1. Potential regional automobile clusters of SMEs, identified by number of firms

New SMEs' clustering is in the Republic of Tatarstan (the main brand is General Motors), Saint Petersburg (Toyota, Hyundai, Kia, Nissan), Kaluga (Volkswagen, Volvo, Peugeot, Mitsubishi) and Kaliningrad (BMW, Kia) regions; most of other potential clusters are based on soviet automobile factories.

\section{Territorial Innovation Clusters Development in Russia}

The Ministry of Economic Development of the Russian Federation initiated competitive selection of projects on development of territorial innovation clusters (TIC) in Russian regions. Regional administrations declared more than 100 cluster initiatives, 25 of which won support from the federal budget for infrastructure development (Abashkin et al., 2012). The selected clusters have to correspond to one of the last stages of cluster development according to tab. 1.

Innovation clusters are located generally in regions with the high level of innovative development (Kutsenko, 2015; Zemtsov et al., 2015) according to the rating of the Association of Innovative Regions of Russia (AIRR) (AIRR, 2013). 13 $(62 \%)$ of the 21 clusters, considered in this work, are located in regions, called "strong innovators", and $5(24 \%)$ - in "medium-strong innovators" regions (see fig. 2)

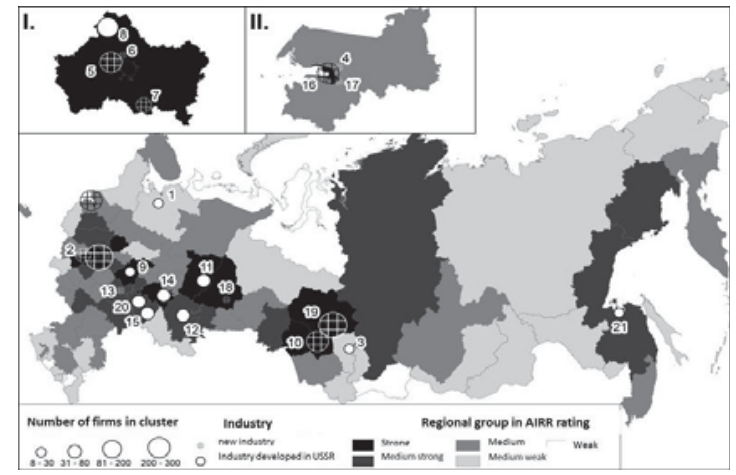

Figure 2. Russian territorial innovation clusters (TIC)

Inset: I - Schematic map of Moscow region and Moscow, II - Schematic map of Leningrad region and St. Petersburg. 
The numbers, shown on the map: 1 - Shipbuilding regional innovation clusters (Arkhangelsk region), 2 - Pharmaceutics, biotechnology and biomedicine cluster (Kaluga region), 3 - Complex of coal processing (Kemerovo region), 4 - Cluster of medical, pharmaceutical industry and radiation technologies (Leningrad region), 5 - Cluster "Zelenograd" (Moscow), 6 Cluster "Fiztech XXI" (Dolgoprudny, Khimki) (Moscow region), 7 - Biotechnological regional innovation clusters in Pushchino (Moscow region) 8 - Cluster of nuclear physics and nanotechnology in Dubna (Moscow region), 9 - Nizhny Novgorod industrial innovation cluster in automobile and petrochemical industries (Nizhni Novgorod region), 10 Regional innovation clusters in the field of information and communication technologies (Novosibirsk region), 11 Regional innovation clusters of rocket engine "Technopolis 'New Star'" (Perm region), 12 - Petrochemical regional clusters (Republic of Bashkortostan), 13 - Energy-efficient lighting and intelligent lighting control systems (Republic of Mordovia), 14 - Kamsky innovation cluster in automobile and petrochemical industries (Republic of Tatarstan), 15 Regional innovation aerospace cluster (Samara region), 16 - Cluster of Information Technology (St. Petersburg), 17 Cluster of pharmaceutical and medical industry (Saint-Petersburg), 18 - Titanium cluster (Sverdlovsk region), 19 Pharmaceuticals, medical technology, information technology and electronics (Tomsk region), 20 - Nuclear Innovation Cluster of Dimitrovgrad (Ulyanovsk region), 21 - Regional innovation clusters of aircraft construction and shipbuilding (Khabarovsk Territory)

Clusters differ by number of participants and industry. It is widely accepted that a cluster should have not less than 30-50 profile companies. The main problem of the identified clusters is insignificant number of SMEs and insufficient level of interaction between them. There are less than 50 SMEs in 18 of the 21 considered clusters.

Eleven clusters are developed based on new industries (information technologies and pharmaceutics), while twelve clusters are based on the former large Soviet enterprises in traditional high-tech industries (aerospace, shipbuilding, nuclear technologies, petrochemistry).

Approved clusters' analysis shows that de facto many of TICs are large industrial territorial production complexes, formed in the Soviet period in the main competitive and knowledge-intensive sectors of that time (aerospace industry, nuclear industry, microelectronics, etc.). Many pilot clusters consist of one large industrial enterprise (with revenue up to $80 \%$ of the cluster's total revenue) and several small suppliers.

Achieved results of potential high-technology clusters identification show, that public policy covers only a small percentage of clusters. Proposed methodology can be used in development of policy advice. There is no government support to clusters in automobile industry, medical instruments and communication equipment production, which were developing industries in Russia before economic crisis.

\section{Conclusion}

The main result of this scientific work is the synthesis of existing theoretical and empirical approaches to clusters' research, classification of clusters by their level of development, corresponding classification of identification methods, modification of the "localization coefficient" method and recommendations for its application in Russia.

All theoretical constructions, explaining emergence and development of SMEs' clusters, can be reduced to three main approaches: localization (or cluster) effects of concentration by A. Marshall (Marshall, 1890; Romer, 1986); increase of competitiveness according to M. Porter (Porter, 1998; Delgado et al., 2010); emergence and development of network structures for SMEs' interaction (Karlsson, 2008).

Definition of a cluster and applied analysis techniques are considerably driven by the level of cluster development and researcher's purposes.

The sufficient condition for cluster identification is a high industrial concentration in the area. Definition for the most developed cluster is significantly broader: group of interacting firms concentrated in one area from one or several technologically interconnected industries within scientific-industrial complex with a system of management, having synergetic (cluster) effects and forming a system with high efficiency. About $95 \%$ of all clusters, studied in literature, do not correspond to the last definition.

Every stage of cluster development corresponds to identification methods; the most widespread are: indexes of localization (concentration) of economic activity, calculation of localization coefficient, balance methods, methods of network analysis with elements of graph theory, sociological methods (in particular a case study), etc. In Russia some methods of regional clusters identification were applied (by M. Porter's techniques), but methods of localization of economic activity analysis and methods of network analysis are rare.

High-tech industries are mostly concentrated in the regions with the largest agglomerations, because the largest cities and closed science cities are the main sources of new technologies in Russia. Most of the identified clusters are based on soviet defence industry enterprises, but several new clusters appeared. 
Russian cluster policy is not based on existing practices of clusters' identification. The latest support measures were based only on cluster initiatives of the regional authorities. This led to the situation when a considerable part of the developed clusters is out of both federal and regional administrations sight, in particular, according to our investigation of high-technology industries, there are no supported clusters in automobile industry, medical instruments and communication equipment production. Most of the Russian territorial innovation clusters are based on Soviet heritage despite the fact that there are many sectors of national economy, where only small and medium enterprises are acting, that have high cluster potential.

The introduced methodology for potential clusters identification is proved to be an efficient instrument of regional cluster policy both for federal and local government. And the results of cluster identification can be properly used for policy advice.

\section{References}

Abashkin, V., Boyarov, A., \& Kutsenko, E. (2012). Cluster Policy in Russia: From Theory to Practice. Foresight-Russia, 6(3), 16-27. [in Russian]

Acs, Z.J., \& Audretsch, D.B. (2009). The knowledge spillover theory of entrepreneurship. Small business economics, 32(1), 15-30.

Acs, Z.J., Audretsch, D.B., \& Feldman, M.P. (1994). R \& D spillovers and recipient firm size. The Review of Economics and Statistics, 76(2), 336-340.

Albino, V., Carbonara, N. \& Giannoccaro, I. (2006). Innovation in industrial districts: An agent-based simulation model. International Journal of Production Economics, 104(1), 30-45.

Anselin, L., Varga, A. \& Acs, Z. (1997). Local geographic spillovers between university research and high technology innovations. Journal of urban economics, 42(3), $422-448$.

Armington, C., \& Acs, Z.J. (2002). The determinants of regional variation in new firm formation. Regional studies, 36(1), 33-45.

Arrow, K.J. (1962). The economic implications of learning by doing. The review of economic studies, 29(3), 155-173.

Asheim, B.T. (1996). Industrial districts as 'learning regions': a condition for prosperity. European planning studies, 4(4), 379-400.

Asheim, B.T., \& Coenen, L. (2005). Knowledge bases and regional innovation systems: Comparing Nordic clusters. Research policy, 34(8), 1173-1190.

Association of Innovative Regions of Russia (AIRR). (2013). Rating of innovative regions for the purposes of monitoring and control (version 2013-2.0). [Online] Available at: http://www.i-regions.org/\#eng (May 29, 2015).

Audretsch, B. (1998). Agglomeration and the location of innovative activity. Oxford review of economic policy, 14(2), 18-29.

Audretsch, D.B., \& Lehmann, E.E. (2005). Does the knowledge spillover theory of entrepreneurship hold for regions? Research Policy, 34(8), 1191-1202.

Aydalot, P. (1988). High technology industry and innovative environments: the European experience. London: Routledge.

Baburin, V. \& Zemtsov, S. (2014). Diffusion of Innovation and 'Five Russias'. Uddevalla Symposium. [Online] Available at: http://papers.ssrn.com/sol3/papers.cfm?abstract_id=2594167 (September 15, 2015)

Baburin, V.L. \& Zemtsov, S.P. (2013). Geography of innovation processes in Russia. Vestnik Moskovskogo Universiteta, Seriya 5: Geografiya, 5, 25-32. [in Russian]

Bair, J. \& Gereffi, G. (2001). Local clusters in global chains: the causes and consequences of export dynamism in Torreon's blue jeans industry. World development, 29(11), 1885-1903.

Baptista, R. (1999). The diffusion of process innovations: A selective review. International Journal of the Economics of Business, 6(1), 107-129.

Beaudry, C. \& Schiffauerova, A. (2009). Who's right, Marshall or Jacobs? The localization versus urbanization debate. Research Policy, 38(2), 318-337.

Boschma, R. (2005). Proximity and innovation: a critical assessment. Regional studies, 39(1), 61-74

Boschma, R., \& lammarino, S. (2009). Related variety, trade linkages and regional growth. Economic Geography, 85(3), 289-311.

Boschma, R., \& Martin, R. (2010). The Handbook of Evolutionary Economic Geography. Cheltenham: Edward Elgar.

Breschi, S., \& Lissoni, F. (2001a). Knowledge spillovers and local innovation systems: a critical survey. Industrial and corporate change, 10(4), 975-1005.

Breschi, S., \& Lissoni, F. (2001b). Localised knowledge spillovers vs. innovative milieux: Knowledge "tacitness" reconsidered. Papers in regional science, 80(3), 255-273.

Bresnahan, T., Gambardella, A., \& Saxenian A.L. (2001). 'Old economy'inputs for 'new economy'outcomes: cluster formation in the new Silicon Valleys. Industrial and corporate change, 10(4), 835-860.

Carlsson, B. (2013). Knowledge flows in high-tech industry clusters: Dissemination mechanisms and innovation regimes. In Pyka, A., Andersen, E.S. (eds.) Long Term Economic Development (pp. 191-221). Berlin: Springer Verlag.

Coe, D.T., \& Helpman, E. (1995). International R\&D spillovers. European economic review, 39(5), 859-887.

Cooke, P., \& Schwarz, D. (2007). Creative regions: technology, culture and knowledge entrepreneurship. London: Routledge.

Crescenzi, R., \& Rodríguez-Pose, A. (2011). Innovation and regional growth in the European Union. Springer Science, Business Media.

Delgado, M., Porter, M.E., \& Stern, S. (2010). Clusters and entrepreneurship. Journal of Economic Geography, 10(4), 495-518.

Duranton, G., \& Overman, H.G. (2008). Exploring the detailed location patterns of UK manufacturing industries using microgeographic 
data. Journal of Regional Science, 48(1), 213-243.

Duranton, G., \& Puga, D. (2004). Micro-foundations of urban agglomeration economies. In Henderson, J.V. \& Strange, W.C. (eds.) Handbook of regional and urban economics (pp. 2063-2117). Elsevier.

Ellison, G., \& Glaeser, E.L. (1999). The geographic concentration of industry: does natural advantage explain agglomeration? American Economic Review, 311-316.

Enright, M.J. (1999). Regional clusters and firm strategy. In Chandler, A., Solvell, O., Hagstrom, P. (eds.) The Dynamic Firm (pp. 315342). UK: Oxford University Press.

Europe Innova, PRO INNO. (2008). The concept of CLUSTERS and CLUSTER policies and their role for competitiveness and innovation: Main statistical results and lessons learned. Europe paper № 9.

Feldman, M.P. (2001). The entrepreneurial event revisited: firm formation in a regional context. Industrial and corporate change, 10(4), 861-891.

Feldman, M.P., \& Audretsch, D.B. (1999). Innovation in cities: science-based diversity, specialization and localized competition. European economic review, 43(2), 409-429.

Fritsch, M. \& Mueller, P. (2007). The persistence of regional new business formation-activity over time - assessing the potential of policy promotion programs. Journal of Evolutionary Economics, 17(3), 299-315.

Fritsch, M., Brixy, U., \& Falck, O. (2006). The effect of industry, region, and time on new business survival - a multi-dimensional analysis. Review of industrial organization, 28(3), 285-306.

Fujita, M., Krugman, P.R., \& Venables, A. (2001). The spatial economy: Cities, regions, and international trade. MIT press.

Hatzichronoglou, T. (1997). Revision of the high-technology sector and product classification. [Online] Available at: http://www.oecd.org/ officialdocuments/publicdisplaydocumentpdf/?cote=OCDE/GD\%2897\%29216\&docLanguage=En (February 22, 2015)

Jacobs, J. (1969). The Economy of Cities. New York: Random House.

Karlsson, C. (2008). Handbook of Research on Cluster Theory. Cheltenham: Edward Elgar.

Keeble, D., \& Wilkinson, F. (1999). Collective learning and knowledge development in the evolution of regional clusters of high technology SMEs in Europe. Regional studies, 33(4), 295-303.

Ketels, C., Lindqvist, G., \& Sölvell, Ö. (2012). Strengthening clusters and competitiveness in Europe: the role of cluster organizations. Stockholm School of Economics.

Kolosovskiy, N.N. (1947). Production and territorial combination (complex) in the Soviet economic geography. Questions of geography, Vol. 6, 133-165. [in Russian]

Krugman, P.R. (1991). Geography and trade. MIT press.

Kutsenko E. (2015). Pilot Innovative Territorial Clusters in Russia: A Sustainable Development Model. Foresight-Russia, 9(1), 32-55.

Lazzeretti, L., Boix, R., \& Capone, F. (2008). Do creative industries cluster? Mapping creative local production systems in Italy and Spain. Industry and innovation, 15(5), 549-567.

Lindqvist, G. (2009). Disentangling clusters: agglomeration and proximity effects. Stockholm: Economic Research Institute, Stockholm School of Economics (EFI).

Lorentzen, A. (2005). The spatial dimensions of innovation. In: European Science Foundation Exploratory Workshop on The Governance of Networks as a Determinant of Local Economic Development. L'institute, The University of Birmingham.

Love, J. H., \& Ganotakis, P. (2013). Learning by exporting: Lessons from high-technology SMEs. International business review, 22(1), 117.

Marshall, A. (1890). Principles of Economics. MacMillan, London

Marshall, A. (1920). Principles of Economics (Revised ed.). London: MacMillan; reprinted by Prometheus Books.

Neffke, F., Henning M., Boschma R. (2011). How do regions diversify over time? Industry relatedness and the development of new growth paths in regions. Evolutionary Geography, 87(3), 237-365.

Nelson, R.R. (1971). Simple Economics of Basic Scientific Research. The Journal of Political Economy, 67(3), 297-306.

North, D.C. (1990). Institutions, institutional change and economic performance. Cambridge university press.

Park, W.G. (1995). International R\&D spillovers and OECD economic growth. Economic Inquiry, 33(4), 571-591.

Pilyasov, A.N. (ed.) (2012). Space synergy: regional innovative systems, clusters and overflows of knowledge. Smolensk: Oikumena. [in Russian]

Polanyi, M. (1967). The Tacit Dimension. London: Routledge \& K. Paul.

Porter, M.E. (1998). Cluster and the new economics of competition. Harvard Business Review, 76(6), 77-90.

Porter, M.E. (2000). Location, competition, and economic development: Local clusters in a global economy. Economic development quarterly, 14(1), 15-34.

Porter, M.E. (2003). The economic performance of regions. Regional studies, 37(6-7), 545-546.

Quah, D., \& Simpson H. (2003). Spatial Cluster Empirics. LSE Economics Department and Institute for Fiscal Studies. [Online] Available at: http://econ.lse.ac.uk/ dquah/p/200306sce.pdf (May 29, 2015)

Romer, P.M. (1986). Increasing returns and long-run growth. The journal of political economy, 94(5), 1002-1037.

Romer, P.M. (1990). Endogenous technological change. Journal of Political Economy, 98(5), 71-102.

Rosenthal, S. \& Strange, W. (2003). Geography, industrial organization and agglomeration. Review of Economics and Statistics, 85(2), 377-393.

Saxenian, A.L. (1991). The origins and dynamics of production networks in Silicon Valley. Research policy, 20(5), 423-437.

Saxenian, A.L. (1996). Inside-out: regional networks and industrial adaptation in Silicon Valley and Route 128. Cityscape: A Journal of 
Policy Development and Research, 2(2), 41-60.

Staber, U. (2001). Spatial Proximity and Firm Survival in a Declining Industrial District: The Case of Knitwear Firms in BadenWurttemberg. Regional Studies. 35(4), 329-341.

Wennberg, K. \& Lindqvist, G. (2010). The effect of clusters on the survival and performance of new firms. Small Business Economics, 34(3), 221-241.

Wever, E., \& Stam, E. (1999). Clusters of high technology SMEs: the Dutch case. Regional Studies, 33(4), 391-400.

Wright, M., Liu, X., Buck, T., \& Filatotchev, I. (2008). Returnee Entrepreneurs, Science Park Location Choice and Performance: An Analysis of High-Technology SMEs in China. Entrepreneurship Theory and Practice, 32(1), 131-155.

Zemtsov, S. (2014). Assessment of innovation potential for Russian regions. ERSA conference papers. [Online] Available at: http://papers.ssrn.com/sol3/papers.cfm?abstract_id=2594351 (October 01, 2015)

Zemtsov, S., Pavlov, P. \& Sorokina A. (2015). Specifics of Cluster Policy in Russia. Institute of Economic Research Working Papers. No. 105/2015. [Online] Available at: http://www.badania-gospodarcze.pl/images/Working_Papers/2015_No_105.pdf (October 01, 2015)

Zhang, S. \& Li, X. (2008). Managerial ties, firm resources, and performance of cluster firms. Asia pacific journal of management, 25(4), 615-633. 